\title{
Annual Conference of the Museums Association
}

$\mathrm{T}$

HE forty-third Annual Conference of the Museums Association was held at Birmingham on June 27July 2, by invitation of the Lord Mayor and Corporation. This is the first time that the Association has visited the City. The University authorities very kindly placed lecture and office accommodation in Mason College, Edmund Street, at the disposal of the delegates, and here some two hundred members of the Association met under the presidency of Sir Henry Miers.

Owing to the prevailing financial conditions, the number of delegates was somewhat smaller than usual, but the Conference was noteworthy in that the social side was reduced to a minimum, and the numerous papers provoked animated, if not always appropriate, discussion.

In his presidential address, Sir Henry Miers gave an encouraging account of the past year's work. With the assistance of the Carnegie United Kingdom Trustees, grants have been made to certain municipal museums for the reorganisation of their collections, and short training courses for curators were held in London and Edinburgh. With the generous cooperation of the Carnegie Corporation of New York, surveys of museums in Canada and Africa were carried out by Sir Henry Miers and Mr. S. F. Markham, in the Mediterranean by the honorary treasurer and honorary secretary of the Association, and of the museums of Montreal by Dr. Cyril Fox, director of the National Museum of Wales. As a result of these surveys, directories of museums in Canada and Africa are in preparation which will contain data hitherto impossible to obtain even from the statistical departments of the appropriate governments.

Other matters of importance concerning museums which Sir Henry dealt with were co-operation between the national and provincial museums, and the expressed desire on the part of the national museums to assist so far as possible the small museums; the Board of Education pamphlet on "Museums and the Schools"; the work of the federations and the recent formation of a new federation, the South-Western Group of Museums and Art Galleries; co-operation with the British Broadcasting Corporation; and the improved status of the curator which is likely to result from the adoption of the diploma scheme. Sir Henry also commented on the increased usefulness of the Museums Journal, and reported that the membership of the Association had increased during the year from 516 to nearly 800 .

At the conclusion of the address, the honorary treasurer (Alderman Charles Squire) presented Sir Henry with two bronze pieces of sculpture by Allan Howes, as a mark of the Association's appreciation of his services as president during the last four years.

Following the presidential address, Dr. G. F. Hill, director and principal librarian of the British Museum, opened a discussion on "Co-operation between National and Provincial Museums". He deplored the splitting up of collections and their subsequent distribution to different centres, as well as the retention locally of unique or historical specimens which fit properly into the series of our great national museums but obviously are out of place, unsafe, and lack true appreciation in the local museum. He also dealt with loan collections and the presentation of duplicates or casts and electrotypes to smaller museums by the larger institutions.

Subsequent speakers from the London museums elaborated these points, and their views appeared to meet with approval from their provincial colleagues. The remainder of the morning was occupied by Miss M. H. Keating's description of a travelling exhibition which she has prepared to illustrate child welfare work, and later in the day the delegates were able to inspect part of Miss Keating's exhibition.

Wednesday provided a varied programme of great interest. Dr. Alexander Scott described the work and methods of the British Museum laboratory in cleaning and restoring metal objects, and the results obtained, as illustrated by lantern-slides, aroused the enthusiasm of the audience and provoked numerous inquiries. Mr. S. L. Davison, of Port Sunlight, described the objects and methods of the Regional Federations of Museums, basing his remarks on his experience with the Lancashire and Cheshire Federation. "Modern Methods of Examining Pictures " was the subject of a delightful and practical exposition by Prof. A. P. Laurie, who made difficulties seem easy and constantly captured the admiration of his hearers by his wide knowledge of the history of pictures and artists. In the afternoon, Dr. L. J. Spencer explained how he illuminated the cases and specimens in the Mineral Department of the British Museum, and thus provoked a discussion of primary importance to the delegates. From the consideration of the lighting of museum cases to that of the illumination of a child's mind is no mean step, but the audience accomplished the transition safely and pleasantly under the guidance of Miss M. Champness, who described her work in the Newbury Museum.

From the subsequent discussion it appears that most curators are agreed that the handling of specimens by the child is of primary importance, while the 'once upon a time' method of telling a story, the provision of seats for the small listeners, and, if possible, the use of a special room away from adult interference, all contribute to the success of the instructional classes.

Most of Thursday morning was devoted to the annual business meeting, but the Association welcomed Mr. R. A. Rendall, of the B.B.C., who inaugurated. a discussion on broadcasting and museums. Mr. Rendall outlined the educational policy of the Corporation, and hoped that the art galleries and museums might assist the broadcast of talks by arranging cognate exhibits, or by installing a loud-speaker in the institution for the benefit of organised discussion groups.

The morning of the last day of the Conference was devoted to a summary, by Mr. G. H. Hill, of publicity methods and extension work as at present practised by museums, and to Mr. D. Payler's description of his work in the Birmingham Museum in preparing economic and other exhibits. Dr. Cyril Fox, as chairman of the Education Committee, outlined the newly prepared scheme for a diploma to be awarded to curators after examination. Space does not permit the explanation here of the detailed proposals, but the scheme found favour, as it is definitely practicable and is based on a high enough standard to ensure the recognition of the diploma as a sound educational and curatorial qualification.

An official visit was paid by the Conference to the Museum and Art Gallery, where the delegates enjoyed the magnificent art collection and the pleasing habitat groups of birds and mammals under the guidance of Mr. S. C. Kaines Smith, the keeper, and Mr. Donald Payler, respectively. An unusually large trade exhibition was also staged in the Art Gallery. 